\title{
Finding Foreign Relations Law in India: A Decolonial Dissent
}

\author{
Prabhakar Singh
}

\section{INTRODUCTION}

[A]s a Justice of the High Court of England ... it is my duty to apply English municipal law, including English foreign relations law ... Questions of foreign affairs arising in English courts have ... English law answers. ${ }^{1}$

Could an Indian judge, as the purveyor of the common law coming from England to India, too, identify a duty to apply Indian 'foreign relations law' (FRL), if any? Could the judge also assert that the questions of 'foreign affairs' arising before Indian courts ought to have Indian law answers? After acknowledging the presence of an established FRL in England, the British High Court in the Muffakham Jah case notably found for Pakistan a foreign relations law' but a 'constitutional law' for India. ${ }^{2} \mathrm{We}$ will do well to remember that while Britain does not have a written constitution, United States has one of the world's shortest written constitutions. ${ }^{3}$ Contrarily, the Constitution of India is the postcolonial world's most detailed text. Needless to say, the Constitution is a significant lens with which to identify the possibility, or not, of an FRL within the law of the land.

In what follows, Section II investigates the origins of FRL that appears to reinforce, in the words of the Commonwealthian D.P. O'Connell, the 'essential unity of all European legal structures' that is 'founded on the moral

1 High Commissioner for Pakistan in the United Kingdom v. Prince Muffakham Jah, [2019] EWHC $255^{1}(\mathrm{Ch})$ para. 85.

2 ' $[\mathrm{V}]$ iewed from the perspective of the law of Pakistan - including her foreign relations law' and 'I also have absolutely no doubt that, viewed from the perspective of the law of India - including in particular her constitutional law'. High Commissioner for Pakistan in the United Kingdom v. Prince Muffakham Jah, [2019] EWHC 2551 (Ch) paras. 83-84.

3 Fali S. Nariman, God Save the Hon'ble Supreme Court (New Delhi: Hay House, 2018) p. 135. 
concord of Western peoples'. ${ }^{4}$ It concludes that the FRL scholars practice a convenient overlooking of the colonial history of the common law. Section III studies the significance Indian Constitution attaches to the international law of states and that of state and peoples and aliens. Since the Indian Constitution does not break free by design from common law, the Indian judges use the Constitution as well as common law to harmonise international law with Indian law. Section IV investigates how the Indian Supreme Court excludes foreign relations from judicial scrutiny. An outcome of this investigation is the fidelity of the Supreme Court to British case laws over the American precedents in its first two decades. ${ }^{5}$ Section $\mathrm{V}$ discusses the Supreme Court's reading of India's postcolonial territory under the uti possidetis lens of international law. The study of uti possidetis for India is significant in that the Supreme Court has created a balance between a fractured reception of territory from the British and the postcolonial government's reception of territory within the Constitution. Indeed, the President of India has from time to time sought the Court's opinion on the executive's power of exchange of territory and cession, like with regard to Pakistan, or the Court has examined the welcoming of new territories, like Sikkim, into the Union of India. Such questions from the executive have allowed the Indian Supreme Court to affirm its Constitutional superiority with deference to the competence of the executive in territorial matters while reading international law in harmony with, what I call, a 'postcolonial common law'. Section VI concludes.

\section{FRL AS THE 'CONCORD OF WESTERN PEOPLES': THE COMMONWEALTH AND COLONIALISM}

\section{A The FRL of the Commonwealth}

An FRL, in Campbell McLachlan's definition, ought to be 'a distinct field in Anglo-Commonwealth legal systems'. ${ }^{6}$ How inclusive is this common law, however, of non settler jurisdictions such as India and Kenya, for example? 'In approaching the question of the existence or otherwise of [a] doctrine in

4 Daniel P. O'Connell, 'Unjust Enrichment' (1956) 5 American Journal of Comparative Law 2 at 4 .

5 Exactly two decades after the Indian independence, in 1967 Justice Subba Rao, against the will of the Indian Government, read the American doctrine of 'prospective overruling' into Indian Law. Fali S. Nariman, India's Legal System: Could it Be Saved? (Gurgaon: Penguin Random House India, 2017 [2006]) pp. 74-5, 158-9.

6 Campbell McLachlan, 'The Allocative Function of Foreign Relations Law' (2012) 82 British Yearbook of International Law 349. 
English law', O'Connell wrote in 1956, 'one must not only appreciate the character of the English legal system, but go further and recognize the essential unity of all European legal structures, a unity founded on the moral concord of Western peoples' ${ }^{7}$

O'Connell was referring to the resistance among the English lawyers in importing a European legal idea calling into service the 'unity founded on the moral concord of Western peoples'. In the twenty-first century, McLachlan's Foreign Relations Law explicitly refers to only four Anglo-Commonwealth states; the United Kingdom, Australia, Canada and New Zealand, ${ }^{8}$ effecting a further provincialisation of the 'concord of Western peoples' - the white excolonies of imperial Britain. Commonwealth lawyers have, as it were, gone out into the woods to pick mushrooms of various laws, if you will, for an FRL soup. The American and the British lawyers have to go mushroom-picking perhaps because they do not have the benefit of a Constitution like India's, the world's largest and enduring. Besides, India, a common law jurisdiction, is expectedly out of the consideration from both the "concord of the Western peoples' as well as the list of jurisdictions to make an FRL from. ${ }^{9}$ Should the FRL scholars look into the deliberations of the Indian Constitution, the conclusion would be that the advocacy for FRL is somewhat provincial.

For McLachlan, an FRL pertains to a

whole class of legal issues and disputes, dealing with: the relationship between public international law and the municipal legal system in the control of foreign relations; the exercise of the foreign relations power by the three organs of government - its legal implications and its limits; the implications of the foreign relations power for the rights of the individual; and the treatment of the foreign state within the municipal legal system. ${ }^{10}$

This class is understandably large. McLachlan claims that FRL 'serves to fill a key gap by extending to the field of public powers the technique of private

7 Daniel P. O'Connell, 'Unjust Enrichment' at 4.

8 Campbell McLachlan, Foreign Relations Law (Cambridge: Cambridge University Press, 2014) refers to only four Anglo-Commonwealth states; the United Kingdom, Australia, Canada and New Zealand.

9 Daron Acemoglu, Simon Johnson and James A. Robinson, 'The Colonial Origins of Comparative Development: An Empirical Investigation' (2001) 91 American Economic Review 1369 at 1370.

10 McLachlan, 'The Allocative Function of Foreign Relations Law', 349; Campbell McLachlan, 'Five Conceptions of the Function of Foreign Relations Law', in Curtis A. Bradley (ed.), The Oxford Handbook of Comparative Foreign Relations Law (New York: Oxford University Press, 2019) pp. 21-43. 
international law - jurisdiction and applicable law' thereby depositing FRL in the domain of the 'constitutional state'."

It is well known that India inherited a common law system from British colonialism. And in 1950 India received her Constitution that was inspired by various civil and common law systems. Does India also have an FRL in the cast and mould made by the Oxford Handbook on FRL? ${ }^{12}$ The Handbook casts a very wide net in so far as crafting an FRL is concerned. And the cast of that FRL net, for the Handbook editor Curtis Bradley, covers not just classic international law. For Bradley, the FRLs 'encompass the domestic law of each nation that governs how that nation interacts with the rest of the world'. We are confronted with the famous Dworkinian question then; could the 'principles' of foreign affairs be passed off as the 'law' of foreign affairs in India? I think not.

We need to first find an FRL in India. Only afterwards could we answer whether there exists or not the possibility of either bridges or boundaries between an Indian FRL and international law. If we take the FRL's scope and definition from the Handbook and combine it with this volume editors' expectations, we might squarely conclude that FRL for India remains primarily a constitutional reading of the international law of states and individuals. ${ }^{13}$

\section{B Overlooking Legal History}

The idiosyncratic judges, scholars, and diplomats in the geographical South should not be easily convinced by the FRL scholarship that is innocent of legal history. ${ }^{14}$ The FRL's first impression on any Asian post-colony is that of a new blueprint of imperialism through law in the twenty-first century because, as Acemoglu, Johnson and Robinson note:

There were different types of colonization policies which created different sets of institutions. At one extreme, European powers set up 'extractive states', [where the colonists] did not introduce much protection for private property,

11 McLachlan, 'The Allocative Function of Foreign Relations Law', 349-50.

12 Curtis A. Bradley, 'What Is Foreign Relations Law?' in Curtis A. Bradley (ed.), The Oxford Handbook of Comparative Foreign Relations Law (New York: Oxford University Press, 2019) p. 3 .

13 Venkatachala G. Hegde, 'Indian Courts and International Law' (2010) 23 Leiden Journal of International Law 53 at 58 .

14 A discursive formation of common law resulting in the transformation of the law of nations in the Indian colony rejects the idea of the periphery as only the receiver of the law. The Indian colony supplied common law to England instead.' Prabhakar Singh, 'Indian Princely States and the 19th-century Transformation of the Law of Nations' (2020) 11 Journal of International Dispute Settlement 365 at 387. 
nor did they provide checks and balances against government expropriation. In fact, the main purpose of the extractive state was to transfer as much of the resources of the colony to the colonizer. At the other extreme, many Europeans migrated and settled in a number of colonies, creating ... NeoEuropes'. The settlers tried to replicate European institutions, with strong emphasis on private property and checks against government power. ${ }^{15}$

It is rather remarkable that, as a legal innovation, FRL is made up of and seeks to export to the rest of the world the common law of 'Neo-Europes' whose ‘[p]rimary examples' for Acemoglu, Johnson and Robinson 'include Australia, New Zealand, Canada, and the United States'. ${ }^{16}$ How exactly does McLachlan's choice of jurisdictions map on to lands where 'Europeans migrated and settled in a number of colonies' beyond Europe? Given this obvious colonial history impacting the choice of the four jurisdictions to make and export FRL from, the postcolonial Indian should be circumspect. Whether such an FRL's legal hermeneutics, in the presence of other ways of doing law - the regular constitutional law for example - will convince the geographical South remains to be seen. ${ }^{17}$

Effectively, from our vantage point, the FRL scholars seem to conveniently overlook legal history. ${ }^{18}$ There are two aspects of that overlooked legal history relevant to the postcolonial common law world. Jurist Fali Nariman reminds us of the first one: a remarkable aspect of 'legal history is that no country which had not at some time or the other been a part of the British Empire has ever voluntarily adopted the common law!'19 Nariman finds it a 'stark fact' that 'whenever there was a choice between common law and the Roman law', the basis of the continental law, 'the decision has always been in favour of Roman law'. ${ }^{20}$

Second, the employment of private law in the service of public law is not so new. The attempts to create FRL as a new field to study law in that sense

15 Acemoglu, Johnson and Robinson, 'The Colonial Origins of Comparative Development', 1370.

16 Acemoglu, Johnson and Robinson, 'The Colonial Origins of Comparative Development', 1370 .

17 To the extent FRL borrows from private law made in the defence of private property and private investors, Ayyangar J. in the Mithibarwala case discredited that 'theory' because 'there could be no analogy between individuals and States' within 'the basic foundations of the rules of [p]ublic [i]nternational [1]aw'. State of Gujarat v. Vora Fiddali Badruddin Mithibarwala, 1964 Indlaw SC 357, para. 51.

18 'A recent book [on FRL] with over 46 chapters does not contain a single chapter or sustained analysis of issues of identity and/race even though the U.S. Foreign Relations paradigm is the defining framework for the book'. James T. Gathii, 'Writing Race and Identity in a Global Context: What CRT and TWAIL Can Learn From Each Other' (2020) 67 UCLA Law Review footnote 191 .

19 Nariman, India's Legal System, p. 23.

20 Nariman, India's Legal System, p. 24. 
mimics the McNair-Lauterpacht school of public law making by private law principles. This stoked Jessup's theoretical innovation soon after the Asian decolonisation aimed at puncturing Asian states' new-found sovereignty by invoking as the applicable law the pro-investor law of the United States. ${ }^{21}$

Walking through the Indian constitutional cases that have settled questions of jurisdiction and applicable law, the fulcrum of FRL's proposal, seems a good starting point for reflection.

\section{THE INDIAN SUPREME COURT BETWEEN PRINCIPLES, POLICY AND THE LAW}

Part 5, chapter 4 of the Indian Constitution talks about 'the Union judiciary'. The Supreme Court of India currently comprises of a Chief Justice and thirty other judges appointed by the President of India. ${ }^{22}$ Under article 143(1) the President has the powers to seek the opinion of the Court about 'a question of law or fact' which is of 'public importance'. The Court 'as it thinks fit, report[s] to the President its opinion'. Article 144 mandates that 'All authorities, civil and judicial, in the territory of India shall act in aid of the Supreme Court'. Very importantly, under article $145(5)$ of the Constitution:

No judgment and no such opinion shall be delivered by the Supreme Court save with the concurrence of a majority of the Judges present at the hearing of the case, but nothing in this clause shall be deemed to prevent a Judge who does not concur from delivering a dissenting judgment or opinion.

The Indian Constitution in providing for the possibility of 'delivering a dissenting judgment or opinion' seeks to balance the majority rule principle of judicial decision-making with the constitutional mandate for judicial idiosyncrasy of separate and dissenting opinions. It bears reminding that this constitutional mandate for dissent has allowed the Indian judges to save India's democratic and secular fabric from the blades of the past and the present authoritarian governments.

\section{A Article 51 of the Constitution and International Law}

Article 51 of the Indian Constitution speaks most directly about international law. It reads as follows:

${ }^{21}$ Prabhakar Singh, 'The Private Life of Transnational Law', in Peer Zumbansen (ed.), The Many Lives of Transnational Law (Cambridge: Cambridge University Press, 2020), p. 419.

22 The Supreme Court of India, https://main.sci.gov.in/constitution [30 September 2020]. 
The State shall endeavour to -

(a) promote international peace and security;

(b) maintain just and honourable relations between nations;

(c) foster respect for international law and treaty obligations in the dealings of organized peoples with one another; and

(d) encourage settlement of international disputes by arbitration.

Since article 51(c) distinguishes 'international law' and 'treaty obligations', the Indian Constitution in such ways recognises both treaty and non-treaty sources of international law. The Indian Supreme Court in the seven bench Maneka Gandhi ruling noted: In the context of expressions like 'security', 'public order', 'public interest' and 'friendly foreign relations', governments come and go, 'but the fundamental rights of the people cannot be subject to the wishful value sets of political regimes of the passing day'. ${ }^{23}$ Maneka Gandhi thus pointed at the permanency of fundamental rights over the political nature of the executive. Maneka Gandhi set a fertile bed for and planted the seeds of Vishaka v. State of Rajasthan to flower later in that the former's emphasis on the 'fundamental rights' nudged the Court in the latter case to import under article 51 from an international convention on the fundamental rights for women. Justice Verma noted in Vishaka:

In the absence of domestic law to formulate effective measures to check [an] evil naturally the contents of International Conventions and norms are significant for the purpose of interpretation of [fundamental rights guarantees] of the Constitutions ... Any International Convention not inconsistent with the fundamental rights and in harmony with its spirit must be read into these provisions to enlarge the meaning and content thereof, to promote the object of the constitutional guarantee. This is implicit from Article 51(c). ${ }^{24}$

Article 51 remains non-justiciable for falling under 'policy' and 'principle' and not 'law' nevertheless. In other words, while one cannot directly invoke a treaty in the Supreme Court that India has not passed into a domestic law, Justice Verma, a champion of human rights, offered a useful elucidation. The Parliament has full powers to enact laws for implementing international conventions by virtue of article 253 read with Entry 14 of the Union List in the Seventh Schedule of the Constitution. And article $73(1)(a)$ provides that the 'executive power of the Union shall extend' to the 'matters with respect to which Parliament has power to make laws'. Next, article $73(\mathrm{l})(\mathrm{b})$ extends the

23 Maneka Gandhi v. Union of India, 1978 Indlaw SC 212, para. 211.

24 Vishaka v. State of Rajasthan And Others, 1997 Indlaw SC 2304, para. 14. 
executive power 'to the exercise of such rights, authority and jurisdiction as are exercisable by the Government of India by virtue of any treaty or agreement'.

We find that the Indian Constitution distinguishes the executive's competence from the 'Parliament's power' and authority to pass a law by virtue of 'any treaty'. The executive power of the Indian Union, Justice Verma said, is therefore available 'till the parliament enacts to expressly provide measures needed to curb a gap in the law'. 25

The executive is under the Constitution vested with residual powers up until the Parliament passes an international treaty into domestic law. The Supreme Court's firm statement of the relationship between international treaties and rights and obligations in municipal law, an assertion of dualism, can be found first in the Maganbhai judgment:

The Constitution of India makes no provision making legislation a condition of the entry into an international treaty in times either of war or peace. The executive is qua the State competent to represent the State in all matters international and may by agreement, convention or treaties incur obligations which in international law are binding upon the State. There is a distinction between the formation and the performance of the obligations constituted by a treaty. Under the Constitution the obligations arising under the agreement or treaties are not by their own force binding upon Indian nationals or others. ${ }^{26}$

Essentially, Maganbhai distinguishes the signing of a treaty by the State from the 'performance' of obligations arising from such a treaty under the Indian law. While the executive is fully competent to sign a treaty, for the treaty to pass into domestic law the Parliament alone can do the lawmaking. Acknowledging this difference, Justice Verma astutely read article 51 as allowing international conventions and treaties becoming only a 'policy' guide for interpreting Indian law so long as such international laws do not conflict with Indian laws. In other words, international law for Vishaka only offers tools for interpretation and not for creating new obligations to arise without a supporting domestic law.

We can therefore hardly say that the 'directive principles' have become justiciable. They continue to remain 'principles' and 'policy' that the Court might remind the executive of, as it sometimes does, to nudge them to pass a suitable law. Article 37 of the Indian Constitution makes it very clear: "The provisions contained in this Part [on directive principles] shall not be enforceable by any court, but the principles therein laid down are nevertheless fundamental in the governance of the country and it shall be the duty of the

25 Vishaka v. State of Rajasthan And Others, 1997 Indlaw SC 2304, para. 14.

26 Maganbhai Ishwarbhai Patel v. Union of India, 1969 SCR (3) 254, para. 79. 
State to apply these principles in making laws'. ${ }^{27}$ On balance, article 37 appears to instruct the Indian state and not the higher judiciary. ${ }^{28}$

We can see that for the Court instructing the executive in territorial matters is a more contested endeavour than importing justice-enhancing norms from human rights treaties. This is so because the Vishaka reads human rights treaties as codified customary laws but the Court generally finds no such thing as customary laws on territory. To then adjudge the Court's views on human rights treaties as a possible rejection of dualism in India is the kind of eagerness that is misleading. Little surprise that we find the anglophile Hidayatullah holding a line harder than the conservative Gajendragadkar in matters of territorial acquisition after decolonisation. ${ }^{29}$ Nevertheless, all laws in India get oxygen from our written Constitution.

\section{B Common Law and the Colonial Continuity}

VP Menon - Constitutional advisor to India's last British Governor General noted: the British 'came to trade, but stayed to rule. They left of their own will; there was no war, there was no treaty - an act with no parallel in history. ${ }^{30}$ India became a fully independent dominion by an Act of the British Parliament, the Indian Independence Act, 1947. The Indian Constitution article 147 therefore defined the 'interpretation' of the Constitution of India to specifically include the reading of the Indian Independence Act, 1947. Legally, as Nariman says, India did not reject common law under its Constitution. ${ }^{31}$ Yet, as Madhav Khosla says, India did not become a case of a 'thoughtless duplication' of British laws. ${ }^{32}$

27 Article 37 of the Indian Constitution of 1950.

28 See generally, Tarunabh Khaitan, 'Directive principles and the expressive accommodation of ideological dissenters' (2018) 16 International Journal of Constitutional Law 389-420.

29 Gajendragadkar for Dhavan 'was the Rooseveltian New Deal judge' and 'only in the 1970s was it discovered that this kind of judge was too closely linked with the government to credit identification with a Holmes or a Cardozo'. Rajeev Dhavan, 'Borrowed Ideas: On the Impact of American Scholarship on Indian Law' (1985) 33 American Journal of Comparative Law 505 at 515. Yet, as Gadbois points out, the 'Anglophile' Chief Justice of India during 1968-70, Hidayatullah and his colleague under his stewardship 'reflected views that were more conservative than during any earlier period'. George H. Gadbois Jr, Judges of the Supreme Court of India: 1950-1989 (New Delhi: Oxford University Press, 2011), p. 136. The Nehru Government curiously enough sent the Bombay High Chief Justice MC Chagla, at the time judge ad hoc in the Right of Passage case, to the United States as India's ambassador. Chagla was later 'appointed as minister in successive governments at the centre'. Nariman, India's Legal System, p. 77. Should we see Nehru pollinating politics with law or vice versa?

30 Vappala P. Menon, The Transfer of Power in India (Hyderabad: Orient Blackswan, 2020 [1957]) p. 436 .

31 Nariman, India's Legal System, p. 23.

32 Madhav Khosla, India's Founding Moment: The Constitution of a Most Surprising Democracy (London: Harvard University Press, 2020) at 20. 
The Indian Constitution has made the Indian Supreme Court the final authority on the reading of the Indian laws. ${ }^{33}$ The Court has the authority to interpret the reception of international law by the municipal courts. At the core of the Indian Supreme Court's foot in the door on international law matters is India's common law tradition as well as the continuity of the colonial laws, precedents as well the various codes passed for the Indian colony after 1857, guaranteed by the Indian Constitution. Article 372(1) of the Constitution guarantees that 'all the law in force in the territory of India immediately before the commencement of this Constitution shall continue in force therein until altered or repealed or amended by a competent Legislature or other competent authority'. ${ }^{34}$ Article 372, if you will, gives Indian judges the licence to practice comparative legal hermeneutics. With the continuity of the colonial laws guaranteed by the Indian Constitution, the Indian courts have a large say in determining and affirming the executive's international legal commitments made before 1947 that is embedded in common law. 35

In 1964, Justice Mudholkar framed the pressing issue of common law, municipal courts, and international law in clear terms. However, 'would the position be different', Justice Mudholkar asked, 'where a particular rule of international law has been incorporated into the common law by decisions of courts?' He noted:

Where Parliament does not modify or abrogate a rule of international law which has become part of the common law, is it open to a municipal court to abrogate it or to enforce it in a modified form on the ground that the opinion of civilized States has undergone a change and instead of the old rule a more just and fair rule has been accepted? ${ }^{36}$

As a matter of 'legal method', a large chunk of the arguments before the Indian Supreme Court for judicial review of the executive actions in international matters are trojan horses for importing British and American precedents. The Indian Supreme Court has under common law kept its umbilical cord with the mother British law intact even as it consistently rejected, up until the

33 Prabhakar Singh, 'Spinning Yarns from Moonbeams: A Jurisprudence of Statutory Interpretation in Common Law' (2021) 42 Statute Law Review, https://doi.org/10.1093/slr/hm yo35, accessed 30 September 2020.

34 Article 372 (1) of the Indian Constitution of 1950.

35 ' $[\mathrm{A}]$ rule of international law on which the several Privy Council decisions as to the effect of conquest or cession on the private rights of the inhabitants of the conquered or ceded territory is founded has become a part of the common law of this country'. State of Gujarat v. Vora Fiddali Badruddin Mithibarwala, 1964 Indlaw SC 357 (Mudholkar J.), para. 180.

$3^{6}$ State of Gujarat v. Vora Fiddali Badruddin Mithibarwala, 1964 Indlaw SC 357 para. 18o. 
1970s, the revolutionary nature of the American precedents. ${ }^{37}$ In a protracted hermeneutical battle of the law, while the executive since 1947 has been inspired by the American independence, the Supreme Court has defended the British common law as the true law for India..$^{8}$ At the core of finding a possible FRL in India rests the local postcolonial common law, the extent of judicial review of the executive function, and the constitutional bind on the executive's competence in withdrawal from international legal obligations existing before $1947 .{ }^{39}$

\section{The Supreme Court and Extradition of Aliens: Policy or Law?}

One of the ways to detect an FRL, McLachlan says, is to evaluate the 'question of the role of law in political matters, whether presented as a plea of nonjusticiability, act of state or political question'.$^{4^{\circ}}$ Yet the foreign affairs exceptionalism cannot be wished away even in states where, to recall O'Connell, 'the essential unity of all European legal structures, a unity founded on the moral concord of Western peoples' is recognised. Let us see how the Indian Supreme Court has treated foreign states before it.

The Hans Muller case arose when the then West German Government requested the extradition of one Mr Muller for offences which he had allegedly committed in West Germany. ${ }^{41}$ Justice Vivian Bose was admittedly forced to 'turn to a wider question' bringing the Indian Supreme Court 'to the fringe of International law'. ${ }^{42}$ The West German Consul at Calcutta had written to the West Bengal Government on 9 October 1954 requesting that the provincial Government issue a 'provisional warrant' of arrest against $\mathrm{Mr}$ Muller, keeping him in custody until the West German Government could

37 'English courts have thus given effect to rules of international law by resorting to a process of incorporation'. State of Gujarat v. Vora Fiddali Badruddin Mithibarwala, 1964 Indlaw SC 357 , para. 181.

38 In Rosiline George v. Union of India 1993 Indlaw SC 1535, the Indian Supreme Court declared 'rights and obligations under all international agreements' to which 'India was a party immediately before 1947, automatically devolved upon India after it achieved independence'.

39 There are no substantive limitations upon the executive from withdrawal from international commitments. Unless there is a Parliamentary process to reject an existing international obligation pre-cast in common law, the Executive cannot arbitrarily withdraw. This has been articulated in by Justice Mudholkar and Justice Lokur respectively. State of Gujarat v. Vora Fiddali Badruddin Mithibarwala, 1964 Indlaw SC 357, para. 180; Verhoeven, MarieEmmanuelle v. Union of India, 2016 Indlaw SC 321, para. 79.

40 McLachlan, 'The Allocative Function of Foreign Relations Law', 375.

${ }^{41}$ Hans Muller of Nurenburg v. Superintendent, Presidency Jail, Calcutta, 1955 Indlaw SC 8.

42 Hans Muller of Nurenburg v. Superintendent, Presidency Jail, Calcutta, 1955 Indlaw SC 8, para. 22 . 
initiate his extradition proceedings. On receipt of this letter, the West Bengal Government sent a note saying it would have 'no objection' in keeping Muller in 'detention'.

Justice Vivian Bose disagreed with the executive, here the provincial government of West Bengal. He did not find 'obvious' within Indian law the Government Secretary's proposal to keep Muller under detention and rejected the executive's position as unfounded, conceding ' $t$ ]his may not be the law in all countries'. ${ }^{43}$ Justice Bose thought that common law courts differed from civil law states in their deference to the executive action. In India, an executive action is governed by common law in the absence of express international law, here, between India and West Germany. Effectively, Justice Bose made a distinction between the common law and the civil law approach on the role of foreign states in domestic courts. Justice Bose rejected the Indian executive's action on the detention of aliens 'without the recommendation of a court'. ${ }^{44}$ The Supreme Court nevertheless held in India the law is that the executive Government has 'an unfettered right' to expel foreigners.

In the Verhoeven, Marie-Emmanuelle case, the Indian Supreme Court had an opportunity to go back to the roots of India's legal basis for foreign relations. ${ }^{45}$ The Annexure to the Report of the Expert Committee No. IX on Foreign Relations contains a list of 627 treaties, conventions, agreements etc. entered into by the Government of India or by the British Government in which India or Pakistan or both were or are interested. This Annexure does not mention the Extradition Treaty between India and Chile. The precise legal issue in Verhoeven was whether the Expert Committee recognized the existence in 2016 of the extradition treaties between the United Kingdom and Chile, and therefore between India, the successor state to the British Indian government, and Chile.

Justice Lokur thought that all international agreements to which India (or British India) was a party would devolve upon the Dominion of India and the Dominion of Pakistan and, if necessary, the obligations and privileges should be apportioned between them. For the Supreme Court there existed "no limitation' in the Indian Independence (International Arrangements) Order of 14 August 1947 in that it was 'only with regard to the 627 treaties' mentioned

43 Hans Muller of Nurenburg v. Superintendent, Presidency Jail, Calcutta, 1955 Indlaw SC 8, para. 35

44 Hans Muller of Nurenburg v. Superintendent, Presidency Jail, Calcutta, 1955 Indlaw SC 8, para. 35 .

45 Verhoeven, Marie-Emmanuelle v. Union of India, 2016 Indlaw SC 321, para. 79. 
by the Expert Committee on Foreign Relations; rather the reference was to 'all international agreements. ${ }^{46}$

\section{EXCLUSION OF FOREIGN RELATIONS FROM JUDICIAL SCRUTINY}

Foreign relations remain excluded from the purview of the Court thereby depositing it into the domain of 'policy' and, consequently, excommunicating it from the province of the law. The actual power of the executive and its primary competence in the field of international affairs suggest that sovereignty remains an important principle. Other common law jurisdictions would not be very different. Prime Minister Nehru, Thiruvengadam says, 'was an ardent champion of judicial review and independence' but at the same time he firmly 'believed that it was Parliament and the government of the day which would have the final say on policy decisions'. ${ }^{47}$ And under 'our jurisprudence', Nariman reminds, 'a law can be enacted by the Parliament or state legislature but generally it comes into effect only when brought into force by a notification of the Government'. ${ }^{8}$ Needless to add, foreign relations stand excluded from judicial scrutiny in India even as the executive could stall lawimplementation on the technical ground of non-notification.

The only way 'foreign relations' as a policy could be brought within the pale of the law is by adjudging the extent of a possible judicial review of the executive actions. I discuss below, in subsection IV.A, the Court's reading of

46 Verhoeven, Marie-Emmanuelle v. Union of India, 2016 Indlaw SC 321, para. 89. Remarkably, the petitioner in Verhoeven relied upon the Government of India's preliminary objections to the assumption of jurisdiction by the ICJ in the Case Concerning the Aerial Incident of 1oth August 1999. Ibid., para. 97 (citing Aerial Incident of 10 August 1999 (Pakistan v. India), Jurisdiction of the Court, I.C.J. Reports 2000, p. 12). In a response to the executive's contention that 'the existence of a treaty is a political question and that this Court cannot go into the issue whether there is a subsisting and binding treaty', the court in Verhoeven found it 'difficult to fully accept the proposition in the broad manner'. Ibid., para. 111. The Delhi High Court in Ellis case tried to clarify the ratio of Verhoeven. 'The petitioner had', Delhi High Court said, 'approached the Supreme Court, inter alia, with the plea that there was no binding extradition treaty in terms of Section 2(d) of the [Indian Extradition] Act between India and Chile. Another plea raised before the Supreme Court was that the requisition made by the Republic of Chile, invoking the principle of reciprocity and the general principles of international law, for extraditing the petitioner from India was not maintainable. The Supreme Court did not accept either of the aforesaid submissions of the petitioner'. Lennox James Ellis v. Union of India, 2019 Indlaw DEL 14, para. 20.

47 Arun K. Thiruvengadam, The Constitution of India: A Contextual Analysis (New Delhi: Bloomsbury, 2017), p. 118.

$4^{8}$ Fali S. Nariman, Before Memory Fades: An Autobiography (New Delhi: Hay House, 2010), p. 82. 
the UN Charter. Finally, this section studies the 'political thicket' question examined by the Indian Supreme Court in the Sikkim case.

\section{A The Indian Supreme Court and the UN Charter}

So far, we have walked through Indian case laws keeping in mind McLachlan's exposition of an FRL. One of McLachlan's stresses is upon the reception and treatment of international law in domestic courts. In this section, I will examine the Indian Supreme Court's treatment of an important regime of international law - the UN Charter.

India sent forces into Goa after the ICJ in the Right of Passage case ruled against Portugal having any military right of passage through Indian territory. ${ }^{49}$ The British government at the time did not recognize India's de facto control of Goa in law (de jure). The Monteiro litigation before the Indian Supreme Court originated from the Goa situation where Father Monteiro having overstayed his residence permit did not apply for the Indian passport. ${ }^{\circ}$ His other options were to either exit the territory of India, or take the offer of the Indian passport without which he would become an illegal 'alien' in Goa. India called her annexation lawful and valid. 'Annexation may sometimes be peaceful', Justice Hidayatullah reasoned, ${ }^{5^{1}}$ 'as for example, Texas and Hawaiian Island were peacefully annexed by the United States or after war, as the annexation of South Africa and Orange Free State by Britain'. ${ }^{2}$

When a title to the new territory actually begins is not an easy question to answer. Since the 'military engagement' in Goa was only 'a few hours' duration' and 'there was no resistance at all', Justice Hidayatullah ruled: 'true annexation followed here so close upon military occupation as to leave no real hiatus'. ${ }^{53}$ According to Justice Hidayatullah,

[t]he occupation on December 20, 1961 was neither belligerent occupation nor anticipated occupation, but true annexation by conquest and subjugation. It must be remembered that Mr. Gardiner, counsel for Father Monteiro, concedes that the annexation was lawful. Therefore, since occupation in the

Case concerning Right of Passage over Indian Territory (Merits), Judgment 12 April 1960, ICJ Report 6.

$5^{\circ}$ Rev. Mons. Monteiro v. State of Goa, 1969 Indlaw $\mathrm{SC}_{5} 83$.

${ }^{51}$ Monteiro is a five-judge bench ruling written by Hidayatullah, a student of McNair at Cambridge. Mohammed Hidayatullah wrote The South-West Africa Case (Bombay: Asia Publishing House, 1967) on the encouragement of his teacher: 'Lord McNair was responsible for my book'. M. Hidayatullah, My Own Boswell (New Delhi: LexisNexis, 2020 [1981]) at 87.

52 Rev. Mons. Monteiro v. State of Goa, 1969 Indlaw SC 583, para. 34.

53 Rev. Mons. Monteiro v. State of Goa, 1969 Indlaw SC 583, paras. 31, 36. 
sense used in Art. 47 [of Convention IV ${ }^{54}$ ] had ceased, the protection must cease also. We are, therefore, of opinion that in the present case there was no breach of the Geneva Conventions. ${ }^{55}$

The Indian justification of Goa's annexation lay in Goa being a Portuguese 'blue-water' province. ${ }^{56}$ Due to India's brush with Portuguese colonialism in the Right of Passage case, ${ }^{57}$ the decade that followed presented a change in the way Indian judges looked at international law. India had sent the Bombay High Court Chief Justice MC Chagla to sit as judge ad hoc on the Right of Passage bench. ${ }^{8}$ A cosmopolitan Nehru at the time suddenly woke up to the reality of India's incomplete decolonization. The fact that Goa, Dadra, and Nagar Aveli continued to be governed by Portugal meant India stood between Lisbon and Portugal's ultramar province, Goa.

While India also stood between Pakistan's two overland provinces East Pakistan (now Bangladesh) and West-Pakistan (now Pakistan), New Delhi did not view these two situations, overseas and overland provinces, similarly. Portugal, in Nehru's words, presented the vestiges of colonialism, particularly after France had returned Pondicherry to India by a treaty and Britain by passing a domestic law. Judge Hidayatullah's reading of the UN Charter naturally acquires significance then. Judge Hidayatullah asserted:

Some would make title depend upon recognition. Mr. Stimson's doctrine of non-recognition in cases where a State of things has been brought about contrary to the Pact of Paris was intended to deny root of title conquest but when Italy conquered Abyssinia, the conquest was recognized because it was thought that the state of affairs had come to stay. Thus, although the United Nations Charter includes the obligation that force would not be used against the territorial integrity of other States (Art. 2 Para 4), events after the Second World War have shown that transfer of title to territory by conquest is still recognized. ${ }^{59}$

54 Geneva Convention Relative to the Protection of Civilian Persons in Time of War, 12 August 1949, 75 UNTS 287.

55 Rev. Mons. Monteiro v. State of Goa, 1969 Indlaw SC 583, para. 37.

56 The Portuguese Permanent Representative to the UN said to the Australian diplomat Sir Owen Dixon, UN Representative for India and Pakistan, that on the Goa question 'a majority of the Council would be in sympathy with the Portuguese, whereas in the General Assembly things might go against the Portuguese'. Letter of AR Moore, May 15, 1958, in Foreign Office Files for India, Pakistan and Afghanistan, 1947-64, Doc DL 1024/2, FO371/135944 (1958) para. 1.

57 Prabhakar Singh, 'India Before and After the Right of Passage case' (2015) 5 Asian Journal of International Law 176.

$5^{8}$ Mahomedali C. Chagla, Roses in December: An Autobiography (Mumbai: Bhartiya Vidya Bhawan, 2018 [1973]), p. 211.

59 Rev. Mons. Monteiro v. State of Goa, 1969 Indlaw SC 583, para. 35. The American professor Quincy Wright, the then editor of the American Joumal of International Law, while visiting New Delhi on Ford Foundation grant found Goa to be a case of Asia's reading of the UN 
We can see that the Indian Supreme Court finds the Indian Constitution, and not the UN Charter, is the applicable law in India. The reference to international law and treaty in article 51 of the Constitution only gives a 'policy' nudge to the Indian executive offering no 'law' to be applied. In December 1960, India's agent before the ICJ in the Right of Passage case, MC Setalvad 'expressed the opinion that there was no legal impediment in incorporating the liberated Portuguese territories into India,.

\section{B The Sikkim Case: The 'Political Thicket' Question}

On 8 May 1973, the King of Sikkim, the Government of India, and leaders of the political parties representing the people of Sikkim entered a tripartite agreement. ${ }^{61}$ Sikkim finally became a province of India in 1975. Justice LM Sharma thought the issue of Sikkim joining India was subject to the 'political questions doctrine'. In other words, 'the questions raised in the petitions pertaining' to the 'terms and conditions of accession of new territory are governed by rules of public international law' and they are as such 'non-justiciable' on the 'political questions doctrine'. ${ }^{62}$ The territory of Sikkim was admitted into the Indian Union by an act of voluntary cession by the general consent of its inhabitants expressed on a Referendum. ${ }^{63}$ The Court invoked the American case Baker v. Carr. ${ }^{64}$ According to the Indian Supreme Court, the effect of Baker v. Carr 'is that in the United States of America certain controversies previously immune from adjudication were held justiciable and decided on the merits. The rejection of the "political thickets" arguments in these cases marks a narrowing of the operation of the doctrine in other areas as well'. ${ }_{5}$, 'The submission is further that', the Court noted, 'since the terms and conditions on which Sikkim was admitted in Union of India, are political in nature, the said terms and conditions cannot be made the subject matter of challenge before this Court because the law is well settled that

Charter. Quincy Wright, “The Goa Question’ (1962) 56 American Journal of International Law $617-32$.

6o Motilal C. Setalvad, My Life: Law and other Things (Mumbai: T. Setalvad \& A. Setalvad, 1990 [1970]) p. 325 .

61 RC Poundyal v. Union of India, 1993 Indlaw SC 1362, para. 120.

62 RC Poundyal v. Union of India, 1993 Indlaw SC 1362, para. 87.

63 RC Poundyal v. Union of India, 1993 Indlaw $\mathrm{SC}_{13} 62$, para. 88. The court here referred to A. K. Pavithran, Substance of Public International Law Western and Eastern (Madras: A. P. Rajendran, 1965) for which Justice Radhabinod Pal wrote the foreword.

64 Baker v. Carr, 369 US 186 (1962).

65 RC Poundyal v. Union of India, 1993 Indlaw SC 1362, para. 17. 
courts do not adjudicate upon questions which are political in nature'. ${ }^{66}$ In the Sikkim case, the Supreme Court moved away from Mithibarwala in that the Court was now open to borrow from common law jurisdictions other than England.

Sikkim joined the Union of India by an international agreement. Irrespective of this agreement, as the later Judge of the ICJ Rosalyn Higgins noted, the UN Human Rights Committee 'questioned' if the treatment of Sikkim, "which had been overrun by force and incorporated within India, was compatible with self-determination'. ${ }^{67}$ Although the Indian Supreme Court decided the Sikkim case four years after Higgins wrote about Sikkim's merger into India, Western scholars often fail to draw a distinction between India's takeover of Goa, a colonial province of Portugal, and Sikkim, an independent Asian kingdom that joined India by an international agreement and a subsequent constitutional process.

Generally speaking, if the Western opinion could so easily question a full political process expressed in the referendum in favour of joining India, and the later incorporation effected under the Constitution of India as 'overrun by force' and not 'compatible with self-determination', it is not difficult to argue that India does not see its Constitution and common law having 'a unity founded on the moral concord of Western peoples'. No wonder justice Mudholkar thought 'the law of a State can only be modified or repealed by a competent legislature of the State and not by international opinion however weighty that Opinion may be'. ${ }^{68}$

Generations of Indian jurists have worked overtime to cultivate and harvest British laws in postcolonial India. ${ }^{69}$ And yet a constitutional reading of international law has remained in the Commonwealth a one-way traffic of precedents and scholarship exposing its imperial bias, the periphery never educating the centre. One does not need to remind that foreign relations are based on reciprocity. There remains an absence of references and reciprocation to Indian case laws on foreign relations in the standard FRL textbooks.

66 The political question doctrine has been evolved in the United States to deny judicial review in certain fields. The doctrine received a setback in the case of Baker v. Carr. Baker v. Carr, 369 US 186 (1962), para. 132.

67 Rosalyn Higgins, 'Human Rights: Some Questions of Integrity' (1989) ${ }_{15}$ Commonwealth Law Bulletin 598 at 608 .

68 State of Gujarat v. Vora Fiddali Badruddin Mithibarwala, 1964 Indlaw SC 357, para. 180.

69 Justice Vivian Bose noted Oppenheim saying the British Government had 'no power to expel even the most dangerous alien without the recommendation of a court'. Hans Muller of Nurenburg v. Superintendent, Presidency Jail, Calcutta, 1955 Indlaw SC 8, para. 35. 


\section{THE INDIAN CONSTITUTION AND UTI POSSIDETIS}

The Indian Constitution doubtless gives the law that the Indian Supreme Court applies. The taking and giving of territory by India too is governed by the Constitution. Territory as defined in the Montevideo Convention is central to the existence of a modern state. ${ }^{70}$ Add to that the doctrine of uti possidetis that instructs former colonies to keep territories and honour boundaries they have received from their colonial masters. But the uti possidetis principle needed a reading by the postcolonial Supreme Court since the colonial masters had defeated in India - by slicing British India into two states - this principle. The new post-colonies bordering India, here Pakistan, went into a further break-up of its territories, creating new sovereign boundaries. This geopolitical situation led India to a constitutive (through the Indian Constitution) and a declaratory (by the executive) re-perfecting of its uti possidetis in the way discussed below.

\section{A Constitutional Perfecting of Uti Possidetis}

In 1959, the President of India wrote to the Indian Supreme Court for an advisory opinion about the questions of law that might arise relating to the Berubari Union as well as the Agreement relating to the exchange of Enclaves with Pakistan. ${ }^{71}$ In the Berubari opinion, Justice Gajendragadkar wrote that, on a 'true construction' of article $1(3)$ (c) of the Indian Constitution, it was erroneous to assume that it confers specific powers to acquire foreign territories. ${ }^{72}$ This opinion noted that cession of national territory in law amounts to the transfer of sovereignty over the said territory by the ownerState in favour of another State. ${ }^{73}$ Justice Gajendragadkar spoke of, if you will, an implied uti possidetis. For him,

It may be that this provision has found a place in the Constitution not in pursuance of any expansionist political philosophy but mainly for providing for the integration and absorption of Indian territories which, at the date of the Constitution, continued to be under the dominion of foreign States; but that is not the whole scope of Art. 1(3)(c). It refers broadly to all foreign territories which may be acquired by India and provides that as soon as they

70 Art. 1, Montevideo Convention on the Rights and Duties of States, 26 December 1933, 165 LNTS 19 .

${ }_{71}$ Re: The Berubari Union and Exchange of Enclaves, 1959 Indlaw SC 294.

$7^{2}$ Re: The Berubari Union and Exchange of Enclaves, 1959 Indlaw SC 294, para. 53.

73 'But though from the human point of view great hardship is inevitably involved in cession of territory by one country to the other', Gajendragradkar said, 'there can be no doubt that a sovereign state can exercise its right to cede a part of its territory to a foreign state'. Re: The Berubari Union and Exchange of Enclaves, 1959 Indlaw SC 294, para. 55. 
are acquired they would form part of the territory of India. Thus, on a true construction of Article 1(3)(c) it is erroneous to assume that it confers specific powers to acquire foreign territories. ${ }^{74}$

The Government of India in Berubari surprisingly did not make a distinction between boundary adjustment and cession. Nevertheless, exactly a decade later, in Maganbhai, ${ }^{75}$ Justice Hidayatullah accepted and confirmed the distinction the West Bengal provincial government had made in Berubari between boundary adjustment and cession:

The argument that if power to settle boundaries be conceded to the Executive, it might cede some vital part of India is to take an extreme view of things. The same may even be said of Parliament itself but it is hardly to be imagined that such gross abuse of power is ever likely. Ordinarily an adjustment of a boundary which International Law regards as valid between two Nations, should be recognised by the Courts and the implementation thereof can always be with the Executive unless a clear case of cession is involved when Parliamentary intercession can be expected and should be had. This has been the custom of Nations whose Constitutions are not sufficiently elaborate on this subject. ${ }^{76}$

'The power to legislate in respect of treaties lies with the Parliament', Justice Hidayatullah continued, '[b]ut making of law under that authority is necessary when the treaty or agreement operates to restrict the rights of citizens or others or modules the laws of the State'. Very importantly, '[i]f the rights of the citizens or others which are justiciable are not affected, no legislative measure is needed to give effect to the agreement or treaty' ${ }^{77}$ Since international law falls within the non-justiciable article 51, rights of the citizens and that of the aliens, legal or illegal, stem from India's written Constitution. ${ }^{78}$

74 Re: The Berubari Union and Exchange of Enclaves, 1959 Indlaw SC 294, para. 53.

75 Maganbhai Ishwarbhai Patel v. Union of India, 1969 Indlaw SC 269.

76 Maganbhai Ishwarbhai Patel v. Union of India, 1969 Indlaw SC 269, para. 42.

77 Maganbhai Ishwarbhai Patel v. Union of India, 1969 Indlaw SC 269, para. 79.

78 Sarbananda Sonawal v. Union of India, 2005, Indlaw SC 404 updates on the 'law regarding deportation of aliens'. In Louis De Raedt v. Union of India, 1991, 3 SCC 664 the Supreme Court clearly held that constitutional rights available to foreigners are restricted to Article 21 of the Constitution. Cf. Prabhakar Singh, 'More Norms, Less Justice: The Refugees, the Republic and Everyone in Between' (2018) 39 Liverpool Law Review 123. 


\section{B Declaratory Perfecting of Uti Possidetis}

While India signed an agreement to welcome Sikkim into the Union of India, almost at the same time, in 1974, the Government of India declared to accept the compulsory jurisdiction of the ICJ 'in conformity with paragraph 2 of article 36 of the Statute of the Court, until such time as notice may be given to terminate such acceptance, as compulsory ipso facto and without special agreement, and on the basis and condition of reciprocity, the jurisdiction of the ICJ over all disputes other than' those mentioned in the Swaran Singh Declaration. ${ }^{79}$ Paragraph 10 of the declaration noted India's exclusion from the ICJ's jurisdiction:

disputes with India concerning or relating to:

(a) the status of its territory or the modification or delimitation of its frontiers or any other matter concerning boundaries;

(b) the territorial sea, the continental shelf and the margins, the exclusive fishery zone, the exclusive economic zone, and other zones of national maritime jurisdiction including for the regulation and control of marine pollution and the conduct of scientific research by foreign vessels;

(c) the condition and status of its islands, bays and gulfs and that of the bays and gulfs that for historical reasons belong to it;

(d) the airspace superjacent to its land and maritime territory; and

(e) the determination and delimitation of its maritime boundaries.

Paragraph 11 of the declaration made it retrospective. India tactically declared its exclusion of the ICJ jurisdiction, in 1974, right before the Third UNCLOS conference began. Why? Might paragraph 10(c) of India's declaration answer this? The declaration excluded from the ICJ disputes about 'the condition and status of its islands, bays and gulfs and that of the bays and gulfs that for historical reasons belong to it'.

India thus secured its uti possidetis in the sea before the UN Convention would fix the substantive content of the law of the sea ( the UNCLOS) putting India's possessions in the sea beyond the UNCLOS. ${ }^{80}$ India has submitted a new Declaration on 27 September 2019 replacing the 18 September 1974 Declaration. In 2019, a new Jaishankar Declaration excluded from the ICJ's

79 Subrahmanyam Jaishankar, 'Declarations recognizing the jurisdiction of the Court as compulsory', 17 September 2019, The ICJ, The Hague, available at: www.icj-cij.org/en/declar ations/in. The 'Jaishankar Declaration' further 'expand[s] the scope of India's reservations'. Srinivas Burra, 'India's Modified Declaration on the Jurisdiction of the International Court of Justice' EJIL Talk (2 April 2020).

8o Prabhakar Singh, 'The Kashmir Question', Deccan Herald, ${ }_{13}$ September 2019, p. 10. 
jurisdiction 'disputes where the jurisdiction of the Court is or may be founded on the basis of a treaty concluded under the auspices of the League of Nations' ${ }^{81}$ By excluding from the ambit of the ICJ's compulsory jurisdiction in 2019 'disputes with the government of any State which is or has been a Member of the Commonwealth of Nations' India has attempted to put its residual uti possidetis beyond the ICJ's adjudication. ${ }^{82}$

\section{CONCLUSION}

The 'decisions of the Privy Council', as Fali Nariman reminds us, 'are called "opinions" because they are in the form of advice to the English Monarch' while the decisions of the House of Lords were known as 'speeches'. ${ }^{3}$ Nehru had accepted Sir BN Rau's formulae to stay within the Commonwealth as a 'Republic' without recognising the British Monarch's moral, legal or political authority. ${ }^{8}$ Should the British 'opinions' to the Monarch and 'speeches' in the House of Lords pre-cast in common law become 'applicable law' in India after 1950? Purshottam Tricumdass, counsel in Mithibarwala, had suggested that the Indian Supreme Court 'discard the theory of public international law that underlies the decisions of the Privy Council' in favour of 'the more rational, just and human doctrine' of the 'American decisions'. His 'thesis', in the words of Justice Ayyangar, 'was that the doctrines evolved by the Privy Council were conditioned by Britain being an Imperialist and expansionist power at the date when they originated and were applied' and that 'these might have been suited to the regime of a colonial power' alone. ${ }^{85}$

In exporting FRL, scholars from common law states seemingly exhibit a lack of sensitivity for the history of common law in British colonies. But for colonialism, common law surely could not have visited India or the other British colonies. The countries that did not suffer British colonialism chose the continental law without exception! ${ }^{86}$ In fact for Nariman 'common law' is not so much a 'law' as it is a 'unique method of administering justice' or, might I add, injustice. After centuries of the reception of the British common law, FRL as a new call to collapse public international law with domestic law

8 Jaishankar, 'Declarations recognizing the jurisdiction of the Court as compulsory', 17 September 2019, The ICJ, The Hague, para. 6.

82 Jaishankar, 'Declarations recognizing the jurisdiction of the Court as compulsory', 17 September 2019, The ICJ, The Hague, para. 2.

83 Nariman, Before Memory Fades, p. 112.

84 Sir BN Rau later become a judge of the ICJ. Setalvad, 'My Life: Law and Other Things', p. 140.

85 State of Gujarat v. Vora Fiddali Badruddin Mithibarwala, 1964 Indlaw SC 357, para. 44.

86 Nariman, India's Legal System, p. 24. 
appears an innocuous innovation only because, as noted before, the FRL scholars overlook the colonial history of common law that jurist Nariman as well as economic historians Acemoglu, Johnson and Robinson point at.

In order to ossify the native sovereignty, the nineteenth century British colonial scholars had argued for an imperial law that was neither international law nor domestic law. Sitting in a post-colony like India, transnational law and FRL appear twins divided by time. In the twenty-first century, FRL scholars argue for a composite 'doctrine derived from public international law, private international law and municipal English law'. ${ }^{87}$ An uncritical growth of FRL happens solely because such an 'Anglo-commonwealth' FRL does not yet recognise law, common law or civil law, of the geographical South as worthy of export. India has gone on a borrowing binge for far too long and an FRL is least desirable in a legal environment of the one-sided traffic of precedents. The common law's unwillingness for learning is not limited to her intellectual apathy for Britain's ex-colonies but extends even to continental law for which O'Connell had exhorted 'the essential unity of all European legal structures, a unity founded on the moral concord of Western peoples'.

But India has inherited a British 'legal structure' without 'a unity founded on the moral concord of Western peoples'. FRL for India remains a moral platitude of the sort O'Connell talked about in relation to Europe and England. Besides being anthropologically challenged, FRL reverses normative decolonisation while claiming to offer a bigger basket of problem-solving.

Many foreign relations issues emerge because of India's marriage to common law. The twenty-first century FRL then appears to uncritically mimic the two older common law projects; 'imperial law' of the nineteenth century Britain and 'transnational law' of the twentieth century post-war United States. We may wish to go by our written Constitution without needing, or having found, a 'foreign affairs' law. Shakespeare famously wrote 'what's in a name'. McLachlan and Bradley think otherwise; everything is in the name. The name is 'foreign relations' law. Not for India, however. Since 1950, it is constitutional law in New Delhi.

87 McLachlan, 'The Allocative Function of Foreign Relations Law', 374. 